\title{
PLEAS FOR PROTECTION OF FISH-EATING BIRD COLONIES REMINISCENCES OF A BIOLOGIST
}

Kees Vermeer

8968 Mainwaring Road

North Saanich, BC V8L $1 J 7$

keesvermeer@telus.net

I began my Canadian Wildlife Service (CWS) career on July 1, 1966. My first job was to evaluate federal migratory bird sanctuaries in Alberta. With a CWS panel truck, I visited all sanctuaries and discovered that they were often set up for the wrong reasons, such as to avoid taxes or keep trespassers out. At the end of the evaluation, I concluded that most sanctuaries were not worth keeping. My travel through the province also provided opportunities to collect data on the distribution and size of nesting colonies and diet of California and Ring-billed gulls. That information expanded the database for my $\mathrm{PhD}$ thesis on those two species.

In the fall I conducted aerial surveys of Trumpeter Swans in the Peace River. Those surveys helped determine the overall reproductive success of swans each year. It was exciting to see the majestic swans with their broods of cygnets on lakes and ponds from the air. The only setback was that I had to empty my stomach on several occasions due to turbulent weather and tight turns flown by the pilot to determine how many cygnets the swans produced.

In December 1966, I was in charge of a CWS program to control the number of overwintering ducks in the Bow River near the Calgary airport. It was a conflict situation as an association called "Friends of the Ducks" fed the ducks regularly, which led to an increase of the duck

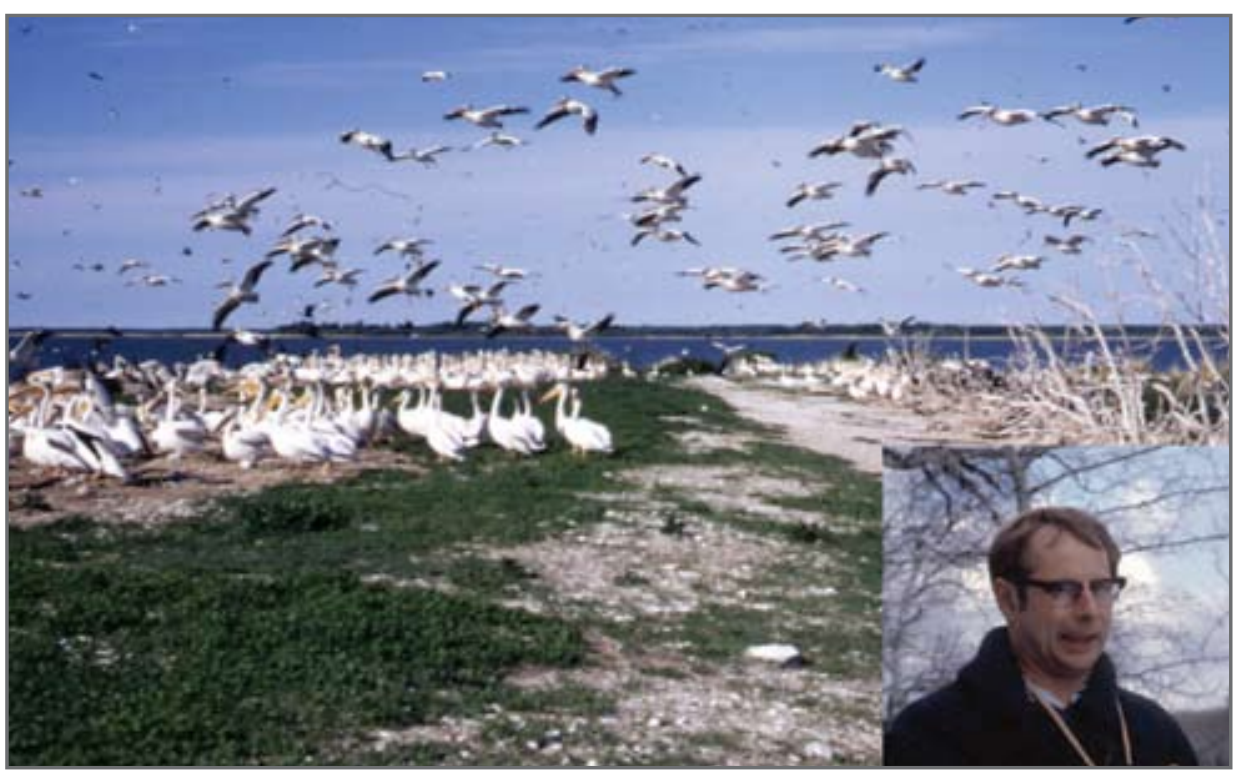

American White Pelicans on reef in Lake Winnipegosis, Manitoba. 1969. Inset: Kees Vermeer. Photo credit: Kees Vermeer

population. However, the airport manager wanted to reduce the number of ducks as they constituted a danger to aircraft. To reduce the duck population, I asked the Royal Canadian Mounted Police (RCMP) to assist me. The RCMP agreed and a dozen officers volunteered to shoot the ducks. Besides the RCMP, half a dozen CWS staff participated. Several hundreds of ducks were donated to the Salvation Army to mitigate any political ramifications that one could expect from such a program. My action proved to be prudent, as later on a non-government organization accused CWS staff of taking the ducks home for personal consumption.

In the summer of 1967, I began a survey of nesting colonies of Doublecrested Cormorants (Phalacrocorax auritus), American White Pelicans (Pelecanus erythrorhynchos) and Great Blue Herons (Ardea herodias) in Alberta, as little was known then about their ecology and population status in that province. Cormorants and pelicans were surveyed at the same time as they often nest on the same islands. Herons were surveyed separately as they nest mostly in trees near water.

After discovering that colonies disappeared because of ongoing vandalism and destruction by humans, the objectives of my investigation changed. I extended the surveys of colonies into Saskatchewan and Manitoba, until the census was complete in the three Prairie provinces. The reason for the extension was to establish a solid foundation of the population status of cormorants, pelicans and herons in the Prairie provinces, which would serve as a basis for measuring future population changes. Another important goal of the investigation became now to inform the Canadian public on the status of endangered colonies and to urge for their 
protection where necessary.

This story is based on reports that are cited in the next sections. They were submitted to journals such as Blue Jay and Canadian FieldNaturalist soon after the surveys were completed in order that either federal or provincial authorities could use the information to protect endangered colonies if they wished to do so.

\section{Cormorants and Pelicans in Alberta and Saskatchewan}

Cormorant and pelican colonies in Alberta were surveyed by car and boat, but also by plane at less accessible places of the province. ${ }^{1}$ Only three small cormorant and four pelican colonies were found. Five cormorant and eight pelican colonies had disappeared by the time of my census. Several of the extinct cormorant and pelican colonies disappeared as a result of human disturbance. .,3 $^{2,3}$ Soper urged sanctuary protection for a pelican colony at Newell reservoir. ${ }^{3}$ No such protection was given and the nesting population of pelicans dwindled from 157 to 27 nests in 1966. No nesting pelicans were observed at Newell reservoir during my survey in 1967.

The next survey was conducted in Saskatchewan in 1968. ${ }^{4}$ Nine cormorant and eight pelican colonies with 1,078 and 6,558 nests were counted, respectively. A pelican colony with 2,256 nests on Backes Island at Primrose Lake proved to be the largest in Canada at that time. Interestingly, Primrose Lake was also within the Canada Air Weapons Range. Eight cormorant and five pelican colonies at 10 lakes had disappeared by the time of my survey. Carson found an American White Pelican colony at Suggi Lake completely destroyed by fishermen in $1964 .{ }^{5}$ He then reported his findings to an official of the Saskatchewan Department of Natural Resources. Carson reported that the official condemned the pelicans as a serious menace to the fishing industry and that no sanction would be given to the birds. Houston described his visits to the American White Pelican colony at Doré Lake as follows: "The conservation officer informed me that local ranchers were in the habit of taking boat loads of eggs from these colonies to feed their mink, rationalizing that the fish-eating birds were harmful to the fishing interests on the lake". 6

\section{Completion of American White Pelican Census in Canada}

In 1969, colonies in Manitoba were surveyed by float plane as many were situated on isolated islands of large lakes. ${ }^{7}$ The Manitoba census, together with a pelican colony investigated at Stum Lake in British Columbia in 1968, and at another one at Lake of the Woods in Ontario in 1969, completed my census of nesting American White Pelicans in Canada. On the basis of a count of 14,103 nests, the total breeding population in Canada was estimated at 30,000 birds for the years 1967-69, seven times higher than previous estimates. ${ }^{7}$ I felt happy for having documented the nesting population of American White Pelicans in Canada, which future census conductors can use for comparison. It was the first serious effort to count the nesting population of American White Pelicans in Canada. Previous estimates were based on reviews of related literature and correspondence with naturalists and ornithologists.

After completing the census, I gained insight on some aspects of the ecology of American White Pelicans, i.e. the interaction between those birds and their environment. It appeared that the breeding range boundaries of American White Pelicans in Canada are chiefly determined by the general availability of fish as controlled by climatic and geological conditions. ${ }^{7}$ Factors affecting nesting pelicans within their breeding range are human disturbance, fluctuating lake levels and mammalian predation. Houston reported that several pelican colonies disappeared as a result of falling lake levels in Saskatchewan. ${ }^{6}$ Blokpoel reported that a family of foxes caused the failure of pelicans to raise any young in 1970 on Backes Island. ${ }^{8}$ Backes Island in Primrose Lake contained the largest colony of American White Pelicans in Canada in 1968. ${ }^{4}$

\section{Cormorants in Manitoba - Status at Lake Winnipegosis after Destruction}

A total of 4,772 nests in 37 active colonies of Double-crested Cormorants were counted in Manitoba in 1969. ${ }^{9}$ The largest nesting concentration of cormorants was found at Lake Winnipegosis, with 1,403 nests in 12 colonies. The Lake Winnipegosis census was important as McLeod and Bondar launched a massive control program of cormorants there during the 1940s and early 1950s. ${ }^{10}$ Thousands of eggs and nestlings were destroyed even though the cormorant diet was composed of only 7.2 per cent commercial fish. Independent of that program, fishermen and loggers also contributed to the destruction of cormorants.

There were 36,000 cormorants on just four of 17 nesting reefs at Lake Winnipegosis at the start of the control program, but only 4,656 nests were counted immediately after its termination in $1951 .{ }^{10}$ Eighteen years later I observed that the cormorant population had dwindled to 1,403 nests, perhaps as a result of further destruction. 


\section{Protection for Cormorant and Pelican Colonies}

Fortunately, there is an upside to the story. In articles and notes, I persisted with my calls for protection of cormorant and pelican colonies in the Prairie provinces. 1,4,11,12,13 It was not until my 1971 publication in the Canadian Audubon "The Pelican protection or extinction" that five colonies were given protection. I concluded that article as follows: "Many islands on which White Pelicans have located their colonies belong to the provincial government and special protection for these would require little money. If the pelican colonies are not protected immediately, so that fishermen and boaters are compelled to leave the birds undisturbed during their nesting period, man will soon be unable to enjoy the sight of White Pelicans soaring majestically against blue prairie skies." Between 1976 and 1983, both cormorants and pelicans had dramatically increased in numbers. ${ }^{14}$

\section{Great Blue Herons in the Prairie Provinces}

Nesting colonies of Great Blue Herons in Alberta were surveyed in 1967 as part of a CWS program to protect threatened birds. ${ }^{15}$ Most heronries were located by asking biologists, wardens and naturalists if they knew of colonies in their areas. Others were found by searching apparently suitable habitats along rivers and around lakes. A heronry with 11 active nests, in low willow bushes on an island in Dowling Lake, was studied in detail in 1968 because of its accessibility.

Most heronries were located in the southern half of the province. A total of 27 colonies were found ranging in size from a few to 55 nests. Eight colonies had been reported to be extinct at the time of my survey,

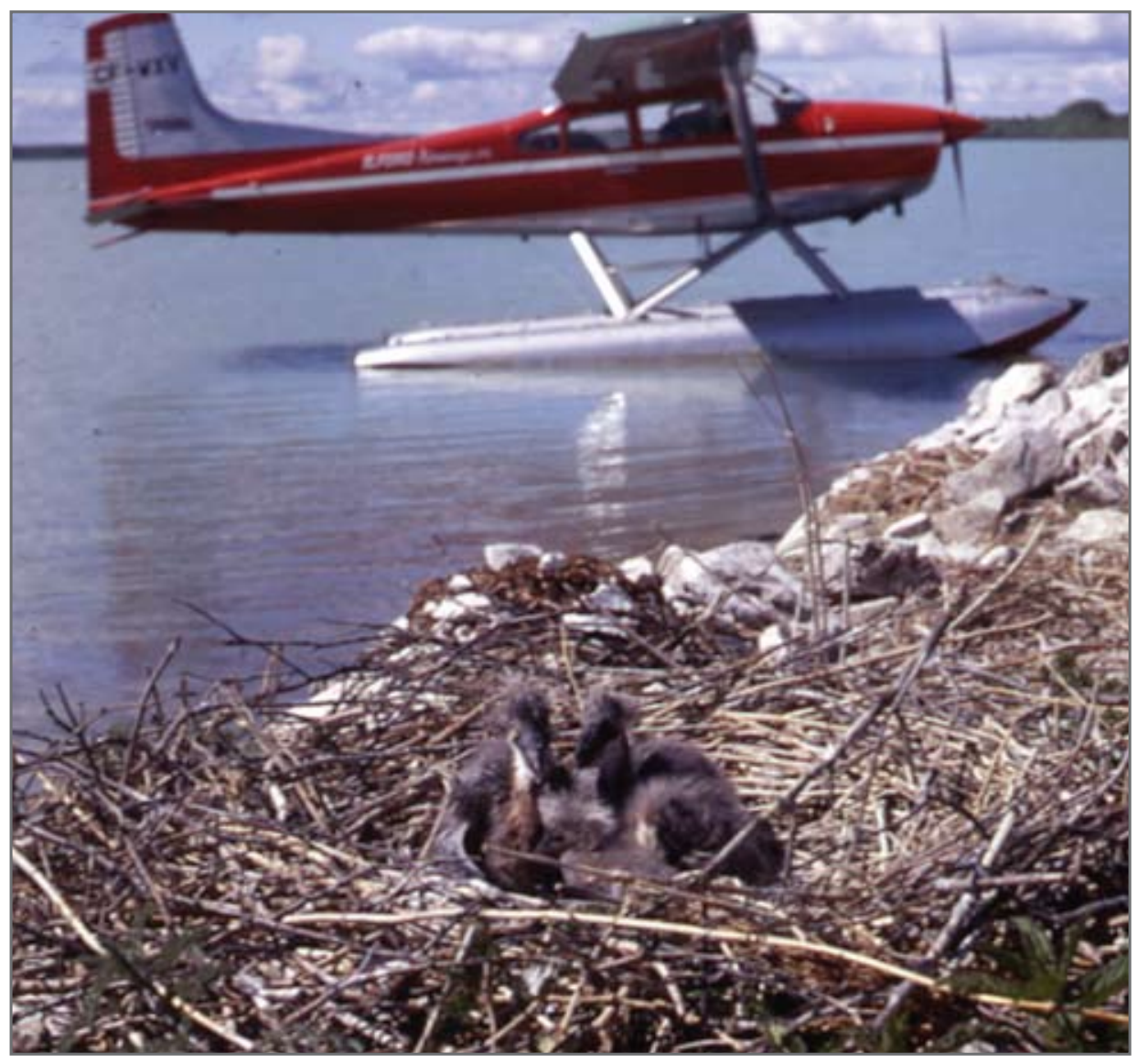

Ground nest of Great Blue Herons at Talbot Lake, Manitoba. 1969. Photo credit: Kees Vermeer

mostly because of vandalism or trees being cut down in heronries. Vandalism continued unabated at some active colonies. One naturalist informed me that 12 herons were shot at one colony resulting in a decline from 10 active nests in 1965 to only one nest in 1967. Another naturalist reported that 15 herons were shot in another heronry. The Dowling Lake heronry disappeared in 1969 because of human disturbance. The herons at that lake may have moved three miles from there to trees along an adjacent pond where they were not observed before. One heronry relocated perhaps because of a pair of Bald Eagles began nesting there.

Heronries in Saskatchewan were surveyed in 1970 and in Manitoba in 1969 and 1971. ${ }^{16,17,18}$ A total of 123 active heronries with 3,764 nests were found in the three Prairie provinces during the 1969-1971 survey. ${ }^{19}$ Based on that figure, it was estimated that the total breeding population of Great Blue Herons in those provinces consisted of at least 4,000 breeding pairs. All heronries were located near water and almost half were on lake islands. All but two of the 123 colonies were observed in trees. Two small colonies were located on treeless islands where herons nested directly on the ground in association with American White Pelicans, Doublecrested Cormorants, Herring and Ring-billed gulls, and Caspian and Common terns. The largest heronries were found in the Lake ManitobaLake Winnipegosis region. The size of 16 colonies in that area averaged 70 nests.

\section{Aquatic Park Proposal for Lake Winnipegosis}

Besides herons, the largest concentration of cormorant and pelican colonies were found in the Lake Manitoba-Lake Winnipegosis region. The concentration of fish- 
eating birds there was thought to relate to an abundant supply of fish in those lakes. ${ }^{19}$ The existence of a rich aquatic bird fauna was the main reason I recommended that Lake Winnipegosis and at least part of Kawinaw Lake and Pelican Lake should be set aside as a federal or provincial park for the birds' protection in an article in Blue Jay. ${ }^{12}$

One reason that the recommendation did not go anywhere is that I failed to go through the proper channels. Perhaps Nature Saskatchewan can "take up the torch from my failing hands" and nominate Lake Winnepegosis as a World Heritage Site because Manitoba does not have a single established or listed site in Canada's Tentative List of World Heritage sites. Parks Canada is the lead agency for implementing the World Heritage Convention and manages the process for Canada. If Lake Winnipegosis becomes a World Heritage site, Canada would be the proud owner of the largest wild freshwater park in central North America.

\section{Meeting Stuart Houston}

My CWS supervisor took me on one occasion to hunt Canada Geese in southern Alberta. After I had shot my first goose and felt sorry for the dead bird, I knew I was not a hunter. Most CWS managers and biologists were then both bird and big game hunters. I wanted more contact with naturalists for whom hunting was not their main hobby. One naturalist I met was Stuart Houston, a Saskatoon physician. Stuart invited me for a weekend of birding in the Saskatoon area. Banding of birds was Stuart's passionate hobby. In an article in Blue Jay entitled

"R.F. Oldaker, the man who reads gull bands with a telescope", he estimated that he had banded "20-thousand-odd birds". ${ }^{20}$ I knew Frank Oldaker, the subject of Stuart's article, very well from my study of Glaucous-winged Gulls on Mandarte Island in British Columbia.

Frank contributed significantly to that study by reading band numbers of gulls I had banded and colour-coded at Mandarte in 1961 and 1962. Frank also produced valuable results for Stuart's large scale project of banding California Gulls in Saskatchewan. A substantial number of Stuart's banded gulls were seen later on by Frank with his telescope in Vancouver. ${ }^{20}$

Stuart, his wife and I had a great time birding, particularly at Redberry Lake where the highlight was a visit to the American White Pelican colony. I also assisted with the banding of a number of nestling pelicans at that lake. It felt like some kind of resource partitioning between two kindred spirits. I documented the status of colonial fish-eating birds and Stuart banded them. Stuart and I kept contact after our first meeting.

As with many stories, one thing leads to another. When the head of a newly established CWS Pesticides Section in Ottawa asked me to join his group because of my involvement with fish-eating birds, which were suspected to have high DDE residue levels as they occupy a high trophic level in the food chain, I was delighted. Shortly after I was transferred to the Pesticides Section where new adventures awaited me.

\section{References}

1. Vermeer K (1969) Colonies of Doublecrested Cormorants and White Pelicans in Alberta. Canadian Field-Naturalist 83:36-39.

2. Farley FL (1922) Summer birds of the Lac La Biche and Fort McMurray region. Canadian Field-Naturalist 36:72-75.

3. Soper JD (1952) Protection of wildfowl breeding grounds in the Lake Newell locality, Eastern Irrigation District, Alberta, Canadian Wildlife Service, Edmonton.

4. Vermeer K (1970) Colonies of Doublecrested Cormorants and White Pelicans in Saskatchewan. Canadian Field-Naturalist 84:39-42.
5. Carson RD (1966) Destruction of colonial birds on an island on Suggi Lake. Blue Jay 24:96-97.

6. Houston CS (1962) Hazards faced by colonial birds. Blue Jay 20:74-77.

7. Vermeer K (1970) Distribution and size of colonies of White Pelicans (Pelecanus erythrorhyncos) in Canada. Canadian Journal of Zoology 48:1029-1032.

8. Blokpoel H (1971) Fox predation on a bird island. Blue Jay 29:32-34.

9. Vermeer K (1969) The present status of Double-crested Cormorants in Manitoba. Blue Jay 27:217-220.

10. McLeod JA, Bondar GF (1953) A brief study of the Double-crested Cormorant on Lake Winnipegosis. Canadian Field-Naturalist 67:1-11.

11. Vermeer K (1970) Some aspects of the nesting of Double-crested Cormorants at Cypress Lake, Saskatchewan in 1969. A plea for protection. Blue Jay 28:11-13.

12. Vermeer K (1970) Aquatic park proposal for Lake Winnipegosis, Kawinaw and Pelican Lakes. Blue Jay 28:66-67.

13. Vermeer K (1971) The Pelican-protection or extinction. Canadian Audubon 33:103-104.

14. Vermeer K, Rankin L (1984) Population trends in nesting Double-crested and Pelagic Cormorants in Canada. Murrelet 65:1-9.

15. Vermeer K (1969) Great Blue Heron colonies in Alberta. Canadian Field-Naturalist 83:237-242.

16. Vermeer K, Anweiler GC (1970) Great Blue Heron colonies in Saskatchewan in 1970. Blue Jay 28:158-161.

17. Vermeer K (1970) Insular Great Blue Heron colonies on large Manitoba Lakes. Blue Jay 28:84-86.

18. Vermeer K, Hatch DRM (1972) Additional information on Great Blue Heron colonies in Manitoba. Blue Jay 30:89-92.

19. Vermeer K (1973) Great Blue Heron and Double-crested Cormorant colonies in the prairie provinces. Canadian Field-Naturalist 87:427-432.

20. Houston CS (1963) R. F. Oldaker, the man who reads gull bands with a telescope. Blue Jay 21:53-57. 